\title{
APLIKASI HUKUM BENFORD DALAM MENGANALISA KASUS GARUDA INDONESIA
}

\author{
Theresia Hesti Bwarleling \\ Program Studi Akuntansi Universitas Bunda Mulia \\ tbwarleling@bundamulia.ac.id \\ Diterima 6 Agustus 2020 / Disetujui 30 Agustus 2020
}

\begin{abstract}
Benford's Law is a simple and effective tool in finding fraud for an auditor. The purpose of this study was to determine whether Benford's Law can be used effectively in analyzing the indication of ambiguity in the financial statements of PT. Garuda Indonesia (Persero) Tbk. 2018. To answer this question, this research uses all accounts in the company's financial statements from 2018 and 2017. In assessing whether these accounts have differences in distribution with Benford's Law, this study uses the average absolute deviation. Then the predicted absolute deviation results are tested by referring to the exposure of Garuda's incidental publications (July, 2019). The results of this study indicate that the value of the financial statements of PT. Garuda Indonesia (Persero) Tbk. in the year 2018 fulfills the Benford Law distribution pattern. Meanwhile, in 2017 there were several deviant account values which were then asked to be restated in the 2018 reporting. Benford's law has once again proven to be used as an effective tool in audit planning.
\end{abstract}

Keywords: Benford Law, Garuda Indonesia Financial Report, Average Absolute Deviation

ABSTRAK: Hukum Benford merupakan alat bantu yang sederhana dan efektif dalam menemukan kecurangan bagi seorang auditor. Tujuan dari penelitian ini adalah untuk mengetahui apakah Hukum Benford dapat digunakan secara efektif dalam menganalisa adanya indikasi kerancuan Laporan Keuangan PT. Garuda Indonesia (Persero) Tbk. Tahun 2018. Untuk menjawab pertanyaan tersebut, riset ini menggunakan seluruh akun dalam laporan keuangan perusahaan tahun 2018 dan 2017. Dalam menilai apakah akun-akun tersebut memiliki perbedaan distribusi dengan Hukum Benford, penelitian ini menggunakan rata-rata deviasi absolut. Kemudian hasil rata-rata deviasi absolut diuji prediksinya dengan merujuk pada paparan publikasi insidentil Garuda (Juli, 2019). Hasil dari penelitian ini menunjukkan bahwa nilai akun Laporan Keuangan PT. Garuda Indonesia (Persero) Tbk. Tahun 2018 memenuhi pola distribusi Hukum Benford. Sedangkan pada tahun 2017 terdapat beberapa nilai akun yang menyimpang dan kemudian diminta untuk disajikan ulang di pelaporan tahun 2018. Hukum Benford sekali lagi terbukti dapat digunakan sebagai alat bantu yang efektif dalam perencanaan audit.

Kata kunci: Hukum Benford, Laporan Keuangan Garuda Indonesia, Rata-rata Deviasi Absolut

\section{Pendahuluan}

Latar Belakang Masalah

Silang pendapat tentang Laporan

Keuangan PT Garuda Indonesia seakanakan memasuki sebuah terowongan yang tanpa berujung. Gagasan dan berbagai pertimbangan, pendapat pro dan kontra, dari berbagai pihak memenuhi ruang media publik tanpa kejelasan sehingga yang tertinggal hanyalah realita yang terus memudar. Selama beberapa kurun waktu, publik hampir merasa kesulitan dalam mengetahui apa yang sesungguhnya sedang terjadi. Pemahaman yang penuh sebenarnya diperlukan agar publik dapat memberikan penilaian secara proporsional atas kinerja keuangan PT Garuda Indonesia.

Manajemen PT Garuda Indonesia (Persero) Tbk secara mengejutkan berhasil menorehkan kinerja yang cemerlang pada tahun 2018. Tidak hanya kondisi kerugian yang membaik (jumlah kerugian berkurang), tetapi bahkan hingga berhasil mencatat laba bersih US\$809,84 ribu atau setara dengan Rp11,33 miliar (Rp14.000 per US\$). Namun sayangnya, alih-alih disambut dengan baik oleh seluruh pihak, ternyata dua komisaris Garuda Indonesia, 
Chairal Tanjung dan Dony Oskaria menepis keberhasilan tersebut dengan mengambil sikap tidak menandatangani laporan buku tahunan Garuda 2018. Kedua figur ini adalah representasi dari PT Trans Airways dan Finegold Resources Ltd selaku pemilik sekaligus sebagai pemegang 28,08 persen saham PT Garuda Indonesia (Persero) Tbk, Pertimbangan dibalik penolakan penandatanganan oleh kedua komisaris tersebut, lebih dikarenakan adanya ketidaksepahaman akan salah satu transaksi kerja sama dengan PT Mahata Aero Teknologi yang dibukukan sebagai pendapatan oleh manajemen.

Seturut dengan penyampaian laporan manajemen dalam Rapat Umum Pemegang Saham Tahunan (RUPST) yang berlangsung pada hari Rabu (24 April 2019) tertera bahwa PT Mahata Aero Teknologi bekerja sama secara langsung dengan PT Citilink Indonesia. Dari hasil kesepakatan perjanjian tersebut, Grup Garuda Indonesia memperoleh keuntungan sebesar US\$239,940,000, dengan sebagian di antaranya yakni senilai US $\$ 28,000,000$ adalah merupakan bagi hasil Garuda Indonesia dengan PT Sriwijaya Air. Namun, hal yang cukup disesalkan adalah karena perusahaan (PT Garuda Indonesia) pada kenyataanya belum meenerima pembayaran dari hasil kerja sama yang dilakukannya tersebut. Tetapi manajemen tetap melaporkannya sebagai pemerolehan pendapatan, sehingga menurut sistem pencatatan akuntansi, PT. Garuda Indonesia dapat mempublikasikan pencapaian laba bersih hingga US\$809 ribu pada tahun 2018 dari sebelumnya merugi sebesar US $\$ 216,58$ juta.

Kedua komisaris Garuda Indonesia, Chairal Tanjung dan Dony Oskaria berargumen bahwa dampak dari pengakuan pendapatan ini cukup menyesatkan dan akan memunculkan kerancuan bagi penalaran publik. Hal ini karena posisi keuangan Garuda Indonesia beralih dari yang sebelumnya merugi menjadi beroleh untung. Selain itu, pencatatan tersebut mengakibatkan Garuda Indonesia menanggung pembayaran beban Pajak Penghasilan $(\mathrm{PPh})$ dan Pajak Pertambahan Nilai (PPN) yang menjadi lebih besar.
Walaupun di satu sisi, beban tersebut seharusnya belum menjadi tanggungan kewajiban PT Garuda Indonesia (Persero) Tbk. karena pembayaran dari hasil kerja sama dengan Mahata belum diterima oleh perusahaan.

Pada tanggal 25 April 2019, kekisruhan ini akhirnya mempengaruhi pasar dengan memberikan respon negatif, sehingga saham perusahaan (dengan kode GIAA) turun tajam hingga sebesar 4,4 persen pada penutupan perdagangan di sesi pertama, Harga saham Garuda Indonesia tergelincir ke tingkat Rp478 per lembar saham dari yang sebelumnya Rp500 per lembar. Pelemahan saham PT Garuda Indonesia (Persero) Tbk. terus berlanjut hingga penutupan perdagangan pada hari Selasa (30 April 2019) ke posisi Rp466 per lembar saham atau turun sebesar 2,5 persen.

PT Garuda Indonesia (Persero) Tbk. memiliki reputasi sebagai salah satu perusahaan Badan Usaha Milik Negara (BUMN) di bidang penerbangan. Oleh karena itu, Bursa Efek Indonesia (BEI) meminta bentuk pertanggungjawaban pihak manajemen Garuda Indonesia terkait munculnya selisih pendapat antara komisaris dengan manajemen terhadap pelaporan keuangan pada tahun buku 2018. Selain itu, pihak otoritas bursa efek juga memanggil kantor akuntan publik (KAP) Tanubrata Sutanto Fahmi Bambang dan Rekan sebagai pihak auditor esksternal yang memeriksa sekaligus memberikan opini atas laporan keuangan Garuda Indonesia.

Pihak Bursa Efek Indonesia (BEI) bukanlah satu-satunya pihak yang memberikan perhatian dalam kasus ini. Komisi VI Dewan Perwakilan Rakyat (DPR) yang membidangi lingkup tugas di bidang industri, investasi dan persaingan usaha, juga turut menyoroti kekisruhan antara komisaris dengan manajemen Garuda tersebut. Wakil Ketua Komisi VI DPR RI Inas Nasrullah Zubir mengatakan perseturuan antara komisaris Garuda Indonesia dengan manajemen telah dijadwalkan untuk dibahas dalam rapat internal seusai masa reses berakhir (www.cnnindonesia.com). 
Pada kasus Garuda 2018 seperti yang telah dijelaskan sebelumnya di atas, kekisruhan yang terjadi tidak akan melebar terlalu jauh jika semua pihak memiliki kesepahaman yang sama akan penerapan Standar Akuntansi yang berlaku di Indonesia. Pengakuan pendapatan Garuda Indonesia ditengarai telah bertentangan dengan PSAK 72 paragraf 28 dan 29. Seturut pernyataan yang tercantum dalam PSAK 72 paragraf 28, pendapatan yang berasal dari penggunaan aset entitas oleh pihak lain yang menghasilkan bunga, royalti, dan dividen diakui dengan dasar pengakuan yang kemudian dijelaskan di paragraf 29 , di mana pendapatan tersebut hanya akan diakui jika dan hanya jika terdapat kemungkinan besar manfaat ekonomi sehubungan dengan transaksi tersebut akan mengalir ke entitas dan jumlah pendapatannya dapat diukur secara andal.

Telah ditegaskan secara spesifik dalam paragraf 29 bahwa royalti hanya diakui sesuai dengan dasar substansi perjanjian yang jelas dan relevan. Selain itu, dalam tambahan penjelasan yang masuk ke lampiran PSAK 72 paragaraf 29, dijabarkan lebih lanjut makna dari PSAK 72 paragraf 28 tersebut bahwa royalti hanya akan diterima atau tidak diterima tergantung sepenuhnya pada kejadian atas suatu peristiwa di masa depan. Berarti dalam hal ini, pendapatan hanya akan diakui jika terdapat kemungkinan besar bahwa royalti tersebut akan diterima oleh perusahaan. Sedangkan di pihak lain, metode pengakuan pendapatan yang diakui oleh Garuda memberikan tanda tanya baik bagi pihak internal (komisaris) maupun beberapa stakeholder lainnya. Penelitian ini akan mencoba menjawab hal tersebut dengan menggunakan aplikasi Hukum Benford.

Aplikasi Hukum Benford adalah salah satu prosedur analitis yang dapat digunakan untuk menganalsa karna metode ini berisikan sebuah analisa digit (Newcomb 1881; Benford 1938). Pada tahun 1920an, dikenal seorang fisikawan yang bekerja pada perusahaan General Electric, bernama Frank Benford. Pada awalnya, Frank cukup terkesan dengan artikel Newcomb pada jurnal matematika di tahun 1800an (Newcomb, 1881). Dalam artikel tersebut, digambarkan sebuah fenomena bagaimana Newcomb baru menyadari bahwa buku logaritma yang selama ini digunakannya itu hanya lusuh pada bagian halaman-halaman awal saja. Jika ditelusuri lebih lanjut, bertepatan dengan fenomena tersebut ternyata halaman-halaman yang lusuh itu merupakan deretan angka kelompok logaritma 1 (satu) sampai 2 (dua). Oleh karena itu, tidak mengherankan jika akhirnya Newcomb menyimpulkan bahwa sebagian besar dari deretan angka yang ada dalam penggunaan prinsip matematika itu mayoritas didominasi oleh kelompok logaritma 1 sampai dengan 2.

Penemuan fenomena inilah yang akhirnya membuat Benford semakin terpacu untuk meneliti lebih jauh, apakah fenomena tersebut hanya berhenti sampai di situ ataukah memang ada skema-skema atau desain tertentu lainnya yang juga terkait dengan kemunculan angka-angka tersebut. Kemudian akhirnya, Frank mencapai tahap penelitiannya hingga pada titik kesimpulan terakhir dengan menemukan sebuah hukum tentang kemungkinan (probabilitas) kemunculan angka, setelah dia meneliti hampir 20 jenis data dengan jumlah sampel penelitian mencapai lebih dari 20.000 buah data. Dasar penelitian Benford ini kemudian digunakan oleh beberapa pihak (baik di bidang akuntansi maupun bidang lainnya) dalam menilai kewajaran pergerakan angka.

Saat ini, penerapan Hukum Benford dalam data akuntansi telah direkomendasikan oleh beberapa pihak terutama untuk data-data keuangan di buku besar (Drake dan Nigrini 2000; Durtschi et al. 2004) dan juga digunakan oleh pihak auditor (pajak) di Indonesia dalam mendeteksi penipuan data keuangan (Prasetyo dan Sinaga 2014). Perkembangan penerapan Hukum Benford dalam pelaporan data keuangan diketahui cukup pesat dan semakin banyak dibahas (Quick dan Wolz 2003; Watrin et al. 2008; Nigrini 2011; Nigrini 2012). Hal ini yang semakin memperkuat argumen untuk dapat mengaplikasikannya khususnya dalam 
menilai kewajaran laporan keuangan Garuda Indonesia.

\section{Identifikasi Masalah}

Standar Akuntansi $\begin{array}{r}\text { Keuangan } \\ \text { pedoman }\end{array}$
Indonesia menyediakan pengakuan pendapatan dan
bagaimana cara pengakuan pendapatan yang
waktu (timing) pengakuan
paling tepat. Manajemen perusahaan dapat
menentukan metode transaksi ekonomi
yang akan dijalankan dengan pihak lain
agar dapat memenuhi pedoman-pedoman Standar Akuntansi Keuangan tertentu, seperti di antaranya Standar Akuntansi Keuangan yang memungkinkan manajemen untuk mengakui suatu penghasilan sekaligus dalam suatu periode, ataupun secara bertahap (beberapa periode) selama jangka waktu perjanjian transaksi. Berdasarkan sudut pandang inilah yang menyebabkan apapun yang akan dilakukan manajemen, secara tidak langsung mereka telah mendapatkan legitimasi. Hal tersebut memberikan ruang dan kesempatan bagi manajemen untuk dapat menjalankan praktik manajemen laba (earnings management) dengan menyiasati periode pengakuan pendapatan.

Merujuk pada perspektif yang telah dijabarkan sebelumnya di atas, maka penelitian ini akan lebih mendalami sejauh mana aplikasi teknik audit (Benford's Law) dapat diterapkan dalam mengidentifikasi kemungkinan adanya kerancuan dalam pengakuan serta pengukuran pendapatan royalti oleh Garuda Indonesia. Kajian ini dimaksudkan untuk menjawab pertanyaan sebagai berikut:

Apakah terdapat perbedaan yang signifikan antara sebaran nilai akun dalam Laporan Keuangan PT Garuda Indonesia (Persero) Tbk. Tahun 2018 dengan Hukum Benford?

\section{Tujuan dan Manfaat Penelitian}

Tujuan kajian ilmiah ini adalah untuk mengetahui apakah terdapat indikasi ketidakbenaran nilai akun dalam Laporan Keuangan PT Garuda Indonesia (Persero) Tbk. Tahun 2018 dan meneliti pada komponen akun apa sajakah indikasi ketidakbenaran tersebut muncul. Selain itu, penelitian ini juga akan menilai adakah kemungkinan keterkaitan antara akun-akun yang menyimpang tadi dengan nilai pendapatan Garuda Indonesia di tahun 2018.

Kajian akademik ini dilakukan untuk memberikan bukti empiris apakah terdapat indikasi ketidakbenaran nilai informasi dalam Laporan Keuangan PT Garuda Indonesia (Persero) Tbk. Tahun 2018 dan menyediakan petunjuk pada komponen akun apa sajakah indikasi ketidakbenaran itu dimungkinkan ada. Serta, kajian ilmiah ini juga dapat dipergunakan untuk mengidentifikasi kemungkinan keterkaitan antara komponen akun-akun yang menyimpang tadi dengan nilai pendapatan Garuda Indonesia di tahun 2018.

\section{Pengembangan Hipotesa}

Dalam konteks investigasi penyelewengan (fraud), jika terdapat perbedaan yang signifikan antara frekuensi aktual dan frekuensi yang diharapkan dari Hukum Benford maka hal ini dapat menjadi indikasi kuat akan adanya kesalahan, penipuan, atau penyimpangan data. Salah satu kajian ilmiah yang telah memberikan gambaran ini adalah penelitan Carslaw (1988) dan Thomas (1989), di mana keduaduanya mencoba menerapkan Hukum Benford untuk menyelidiki kemungkinan adanya manipulasi laba bersih dalam laporan keuangan yang telah dilaporkan oleh pihak perusahaan. Carslaw menemukan bukti bahwa frekuensi kemunculan digit kedua tertentu (terutama nol) yang terkandung dalam angka laba bersih beberapa perusahaan Selandia Baru jauh berbeda dari ekspektasi. Secara khusus, ia mengamati frekuensi yang jauh melebihi ekspektasi Hukum Benford pada angka 0 dan frekuensi yang kurang dari ekspektasi Hukum Benford pada angka 9 untuk posisi digit kedua. Penelitian Carslaw ini kemudian dilanjutkan oleh Thomas dengan melakukan investigasi untuk menentukan apakah pendapatan yang dilaporkan dari perusahaan-perusahaan Amerika Serikat mengikuti pola yang sama dengan perusahaan-perusahaan yang ada di Selandia Baru, berdasarkan kerangka kerja Hukum Benford. Kemudian dilanjutkan oleh penelitian yang dilakukan Nigrini 
(1996) yang berusaha mengaplikasikan Benford's Law untuk mengetahui tingkat kepatuhan wajib pajak. Sedangkan dalam mendeteksi adanya fraud, Durtschi dkk (2004) berhasil menunjukkan keefektifan dari Hukum Benford. Sementara untuk penelitian di Indonesia, pada tahun 2014 pihak Badan Pendidikan dan Pelatihan Keuangan (BPPK) Kementerian Keuangan Republik Indonesia juga melakukan kajian dalam menginvestigasi ketidakpatuhan SPT Wajib Pajak dengan menggunakan Hukum Benford (Kristian Agung Prasetyo dan Suhut Tumpal Sinaga, 2014).

$\begin{array}{ccc}\text { Dengan } & \text { menggunakan dasar } \\ \text { pemikiran } & \text { inilah } & \text { yakni }\end{array}$
perbedaan/penyimpangan pola yang terjadi antara angka aktual pada laporan keuangan dengan angka yang diharapkan berdasarkan Hukum Benford yang berhasil menunjukkan kemungkinan terjadinya fraud, maka diasumsikan bahwa pola penyimpangan frekuensi menunjukkan adanya fraud. Oleh karena itu semakin besar pola penyimpangan berdasarkan Hukum Benford, maka akan mengakibatkan semakin besar munculnya temuan audit. Sehingga dikembangkan hipotesis alternatif yakni bahwa terdapat perbedaan nilai akun yang cukup signifikan dalam Laporan Keuangan PT Garuda Indonesia (Persero) Tbk. Tahun 2018 dengan Benford's Law yang kemudian dapat digunakan sebagai petunjuk dalam menyelidiki nilai akun pendapatan.

\section{Metode Penelitian}

\section{Benford's Law (Uji Digit)}

Beberapa tahun setelah

dicetuskannya Hukum Benford (Frank

Benford, 1938), berbagai bentuk pengaplikasian dari penerapan hukum ini terus dikembangkan, salah satunya melalui penelitian Mark J. Nigrini (1996). Jika, pada Hukum Benford, pengujian kepatuhan sebaran data diukur hanya dengan menggunakan patokan digit pertama maka Nigrini menawarkan lebih daripada itu. Melalui pengembangan konsep yang ia lakukan, Nigrini berhasil menemukan tambahantambahan pola tertentu dengan lebih cermat. Secara ringkasnya akan dipaparkan lebih lanjut melalui penjelasan berikut di bawah ini:

$\begin{aligned} \text { i. } & \text { Tes Digit Pertama } \\ \text { ii. } & \text { Tes Digit Kedua } \\ \text { iii. } & \text { Tes Dua Digit Pertama } \\ \text { iv. } & \text { Tes Tiga Digit Pertama } \\ \text { v. } & \text { Tes Dua Digit Terakhir }\end{aligned}$

Perlu diketahui bahwa tes digit pertama dan kedua adalah tes dengan kualitas pengujian kewajaran yang lebih tinggi dan akan digunakan untuk menentukan apakah set data yang diteliti mengikuti pola Hukum Benford secara wajar atau tidak. Jika tes digit pertama dan kedua menunjukkan bahwa sebaran pola data secara signifikan berbeda dari Hukum Benford, maka barulah dua digit pertama dan tiga digit tes pertama akan dilakukan untuk memilih kemudian dapat diarahkan dalam memilih target audit. Sedangkan untuk tes dua digit terakhir digunakan hanya untuk mendeteksi kewajaran pembulatan nilai.

Pengujian pada model tes tingkat pertama adalah meliputi tes angka pertama, tes angka kedua, serta tes dua digit pertama. Tes tingkat pertama biasanya dijalankan pada deretan bilangan positif ataupun bilangan negatif, tetapi kedua-duanya tidak masuk dalam analisa yang sama. Hal ini dikarenakan dalam praktek nyata, tentunya terdapat insentif yang berbeda antara niatan untuk memanipulasi dengan bilangan positif ataupun dengan angka yang negatif. Misalnya saja, jika sebuah perusahaan memiliki laba bersih positif, manajemen tentunya ingin memanipulasi angka ini dan bahkan kemungkinan akan melebihlebihkannya. Namun di sisi lain, jika perusahaan melaporkan adanya rugi bersih, maka manajemen mungkin menginginkan agar jumlah ini sedekat mungkin mendekati angka nol.

\section{i. Tes Digit Pertama}

Pada pengujian model tes digit pertama akan dibandingkan distribusi frekuensi digit pertama dari suatu set data aktual dengan sebaran distribusi yang dikembangkan oleh Benford. Tahap 
ini merupakan tes dengan tingkatan yang sederhana dan sifatnya hanya untuk mengidentifikasi dengan jelas anomali yang ada (yaitu, hanya dengan mengarahkan pengamat ke arah pola distribusi yang semestinya). Oleh karna itu, seharusnya tes pada tingkatan ini belum dapat digunakan untuk memilih target dalam pengambilan sampel, karena ukuran sampel yang ditargetkan akan menjadi terlalu besar. Misalnya, perhatikan perbandingan grafik berikut dari set Benford (digit pertama frekuensi sesuai dengan Hukum Benford) dan kumpulan sampel data (Kumpulan Data X). Asumsikan kumpulan Data $\mathrm{X}$ merupakan frekuensi digit pertama dari 20.000 faktur pemasok.

Tabel 1. Contoh Penyimpangan Data pada Tes Digit Pertama

\begin{tabular}{cccc}
\hline Digit Pertama & Hukum Benford & Data X & Deviasi \\
\hline $\mathbf{1}$ & $30.10 \%$ & $24.00 \%$ & 0.06 \\
$\mathbf{2}$ & $17.61 \%$ & $18.00 \%$ & 0.00 \\
$\mathbf{3}$ & $12.49 \%$ & $26.00 \%$ & -0.14 \\
$\mathbf{4}$ & $9.69 \%$ & $11.00 \%$ & -0.01 \\
$\mathbf{5}$ & $7.90 \%$ & $7.40 \%$ & 0.00 \\
$\mathbf{6}$ & $6.70 \%$ & $7.00 \%$ & 0.00 \\
$\mathbf{7}$ & $5.80 \%$ & $5.00 \%$ & 0.01 \\
$\mathbf{8}$ & $5.12 \%$ & $2.00 \%$ & 0.03 \\
$\mathbf{9}$ & $4.58 \%$ & $2.00 \%$ & 0.03 \\
\hline
\end{tabular}

Sumber : Association of Certified Fraud Examiners, USA

Grafik 1. Contoh Penyimpangan Data pada Tes Digit Pertama

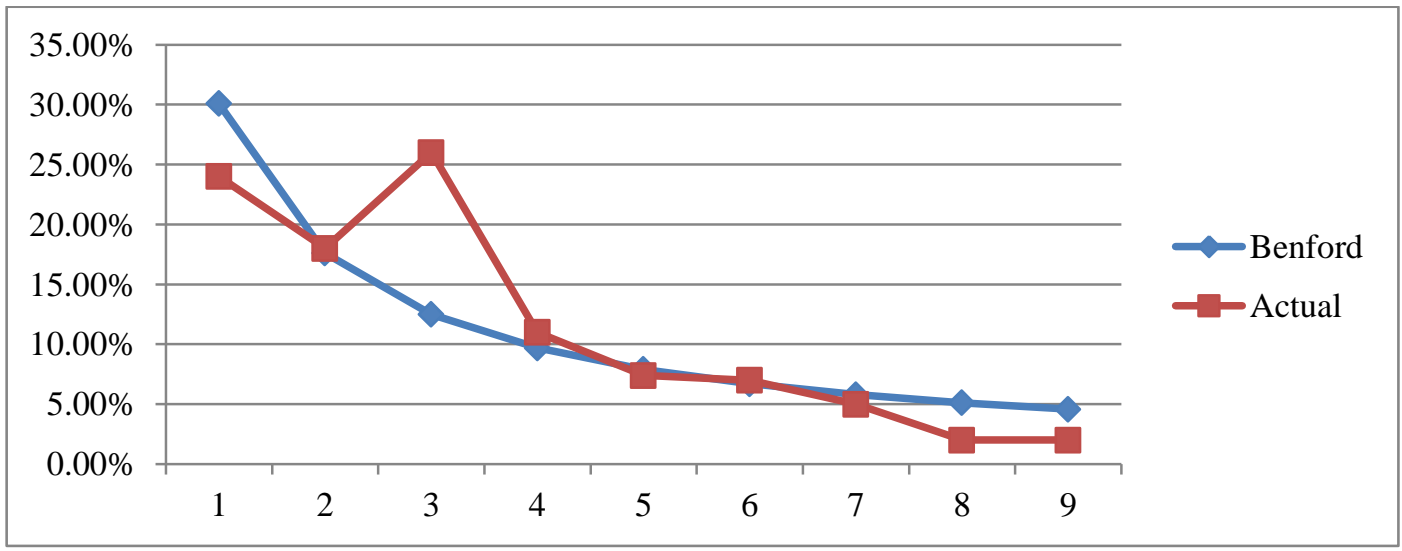

Sumber : Association of Certified Fraud Examiners, USA

Merujuk pada grafik di atas, dapat terlihat pola penyebaran distribusi frekuensi digit pertama dari Data $\mathrm{X}$ tidaklah sesuai dengan Hukum Benford. Bahkan seperti yang dapat dilihat dalam grafik, anomali secara signifikan terlihat sejak angka 3 sebagai digit pertama, di mana jumlah faktur yang nilai nominalnya dimulai dengan angka 3 muncul sebanyak 26\% dan ini berbeda jauh dengan persentase kemunculan yang dihitung oleh Benford yakni sebesar 13\%. Bentuk anomali yang lain juga terdapat dalam penyebaran paket Data $\mathrm{X}$ 
ini, di mana jumlah frekuensi aktual kali ini kurang dari yang seharusnya seperti yang telah ditentukan dalam sebaran frekuensi Hukum Benford. Sebagai seorang auditor, jika melihat penyebaran data seperti contoh di atas tentu akan menarik kesimpulan bahwa pelaku penipuan cenderung sering menggunakan faktur-faktur dengan pola digit tertentu dalam merekayasa pelaporan keuangan. Di mana digit-digit tersebut di antaranya 1, 8, dan 9; dengan penggunaan yang paling berlebihan pada angka 3 sebagai digit pertama. Dengan berfokus pada faktur-faktur yang nilai nominalnya diawali dengan angka 3 dan dikarenakan paket Data X terdiri dari 20.000 faktur, maka artinya auditor perlu memeriksa sekitar 5.200 faktur $(20.000 \times 0,26)$ untuk melihat kembali kewajaran distribusi frekuensi angka 3 sebagai digit pertama. Namun mengingat bahwa usaha ini akan membutuhkan energi dan waktu yang cukup besar, maka hasil tes pada tingkat pertama ini sebaiknya tidak digunakan sebagai pilihan sampel audit. Sebaliknya, hasil tes digit pertama hanya dapat digunakan sebagai patokan awal bagi seorang auditor.

\section{ii. Tes Digit Kedua}

Tes digit kedua juga merupakan tes tingkat sederhana yang dirancang untuk menguji derajat kesesuaian atau kewajaran sebaran data. Perlu diingat bahwa proporsi sebaran digit kedua yang diharapkan dalam Hukum Benford memiliki derajat kemiringan yang lebih kecil dibandingkan dengan proporsi digit pertama (Kellerman, 2014). Dikarenakan hasil tes ini juga akan memberikan jumlah sampel yang besar, maka sama seperti tes sebelumnya (tes digit pertama) pengujian ini tidak disarankan untuk digunakan dalam penentuan sampel audit. Namun, hanya bisa digunakan oleh auditor untuk dengan cepat mengidentifikasi adanya potensi masalah dalam sekumpulan data.

Tabel 2. Sebaran Proporsi Data pada Tes Digit Kedua, Digit Ketiga dan Digit Keempat

\begin{tabular}{ccccc}
\hline Angka & Digit Pertama & Digit Kedua & Digit Ketiga & $\begin{array}{c}\text { Digit } \\
\text { Keempat }\end{array}$ \\
\hline $\mathbf{0}$ & & 0.11968 & 0.10178 & 0.10018 \\
$\mathbf{1}$ & $30.10 \%$ & 0.11389 & 0.10138 & 0.10014 \\
$\mathbf{2}$ & $17.61 \%$ & 0.10882 & 0.10097 & 0.10010 \\
$\mathbf{3}$ & $12.49 \%$ & 0.10433 & 0.10057 & 0.10006 \\
$\mathbf{4}$ & $9.69 \%$ & 0.10331 & 0.10018 & 0.10002 \\
$\mathbf{5}$ & $7.90 \%$ & 0.09668 & 0.09979 & 0.09998 \\
$\mathbf{6}$ & $6.70 \%$ & 0.09337 & 0.09940 & 0.09994 \\
$\mathbf{7}$ & $5.80 \%$ & 0.09035 & 0.09902 & 0.09990 \\
$\mathbf{8}$ & $5.12 \%$ & 0.08757 & 0.09864 & 0.09986 \\
$\mathbf{9}$ & $4.58 \%$ & 0.08500 & 0.09827 & 0.09982 \\
\hline
\end{tabular}

Sumber : Association of Certified Fraud Examiners, USA

iii. Tes Dua Digit Pertama

Untuk model pengujian tingkat berikutnya adalah tes dua digit pertama yang menggabungkan dua tes sebelumnya dan mengidentifikasi penyimpangan nyata yang akan diperlukan lebih lanjut dalam ulasan auditor. Oleh karena itu, pengujian tingkat ini dapat digunakan untuk memilih 
sampel audit secara lebih efisien. Sebagai contoh, dengan menggunakan kembali sampel Data $\mathrm{X}$ dalam uji digit pertama di atas. Banyak sekali faktur yang dimulai dengan 3 yang telah terdeteksi sebelumnya. Bahkan, berdasarkan ulasan tersebut, terdapat sekitar 5.200 faktur yang seharusnya perlu segera diperiksa. Namun sebaliknya, dengan menggunakan tes dua digit pertama, auditor tidak perlu menggunakan seluruh faktur (5.200 faktur) dalam sampel audit berdasarkan uji digit pertama tadi (lihat tabel dan bagan berikut).

\section{Catatan:}

Dalam membaca grafik di bawah ini adalah dengan mengasumsikan bahwa digit pertama dari nomor multi-digit data adalah 3.

Tabel 3. Sebaran Proporsi Data pada Tes Dua Digit Pertama

\begin{tabular}{cccc}
\hline .Digit Pertama & Hukum Benford & Data X & Deviasi \\
\hline $\mathbf{0}$ & $1.42 \%$ & $1.44 \%$ & -.02 \\
$\mathbf{1}$ & $1.38 \%$ & $1.78 \%$ & .40 \\
$\mathbf{2}$ & $1.34 \%$ & $1.12 \%$ & .22 \\
$\mathbf{3}$ & $1.30 \%$ & $1.69 \%$ & -.39 \\
$\mathbf{4}$ & $1.26 \%$ & $1.29 \%$ & -.03 \\
$\mathbf{5}$ & $1.22 \%$ & $1.00 \%$ & .22 \\
$\mathbf{6}$ & $1.19 \%$ & $0.99 \%$ & .10 \\
$\mathbf{7}$ & $1.16 \%$ & $1.12 \%$ & .04 \\
$\mathbf{8}$ & $1.13 \%$ & $1.15 \%$ & -.02 \\
$\mathbf{9}$ & $1.10 \%$ & $1.05 \%$ & .05 \\
\hline
\end{tabular}

Sumber : Association of Certified Fraud Examiners, USA

Grafik 2. Contoh Penyimpangan Data pada Tes Dua Digit Pertama

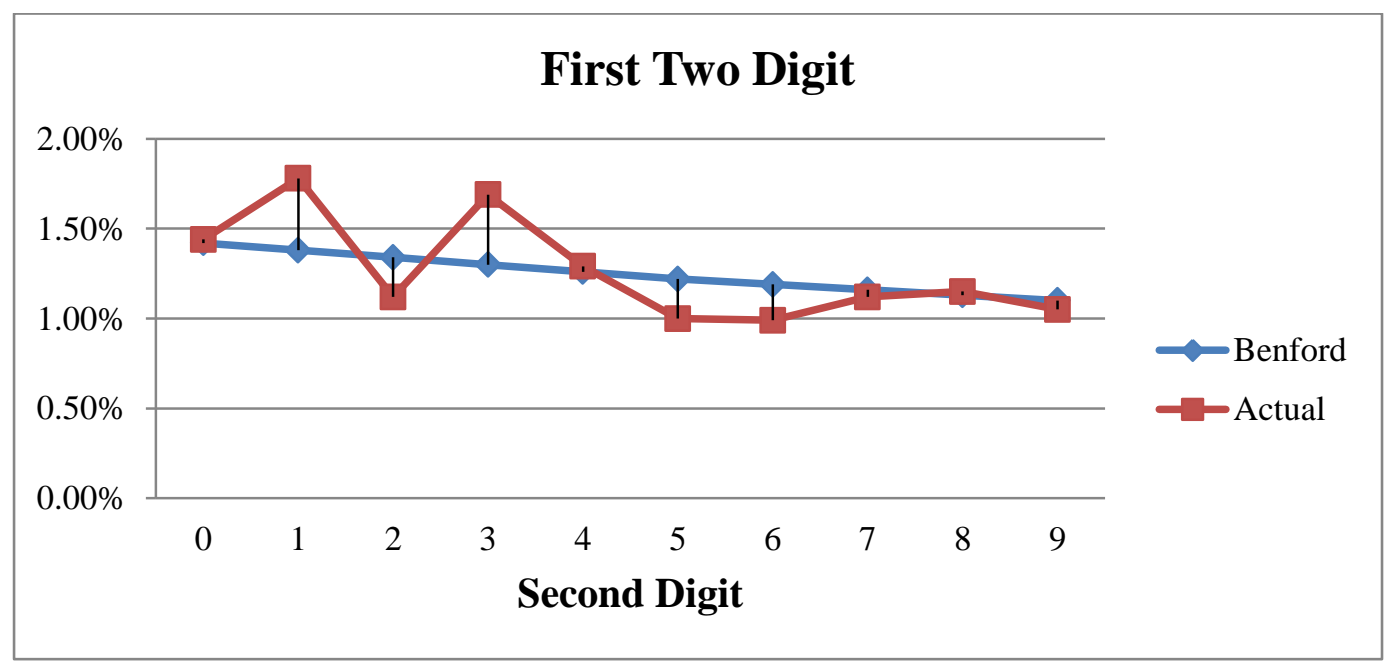

Sumber : Association of Certified Fraud Examiners, USA

Dapat dilihat dalam tabel dan grafik di atas, bahwa ternyata hanya faktur yang dimulai dengan dua digit pertama 31 dan 33 sajalah yang perlu diperiksa. Seperti yang terlihat pada grafik, rangkaian angka ini adalah dua digit pertama yang 
frekuensi aktualnya paling berbeda sendiri dibandingkan dengan frekuensi yang diharapkan dalam Hukum Benford (yakni masingmasing -40 dan -39). Oleh karena itu, jika auditor hanya memfokuskan pemeriksaan pada faktur-faktur dengan nilai nominal yang dimulai dengan angka 31 atau 33, maka auditor hanya perlu meninjau ulang kembali sebanyak 694 (356 + 338) faktur. Jumlah faktur ini didapat dari perhitungan berikut yakni dengan mengalikan antara persentase frekuensi aktual untuk dua digit pertama $31(1,78 \%)$ dengan 20.000 (jumlah faktur total) dan menambahkannya ke 1,69\% (persentase frekuensi aktual untuk dua digit pertama 33) kali 20.000 (jumlah total faktur). Tes ini menghasilkan jumlah sampel audit yang lebih sedikit karna berkurang sebanyak lebih dari 4.500 faktur dibandingkan dengan hasil pengujian sebelumnya (tes digit pertama sebanyak 5.200 faktur) dan tentu saja lebih efisien serta pemeriksaan auditor dapat menjadi lebih terarah.

\section{iv. Tes Tiga Digit Pertama}

Model pengujian tiga digit pertama memiliki karakteristik tes yang sangat fokus dan tes ini juga digunakan dalam memilih serta menentukan jumlah sampel audit. Jika sebelumnya pada model tes dua digit yang pertama cenderung memiliki fungsi untuk menunjukkan kategori abnormal data secara lebih terarah (faktur dengan nilai nominal yang diawali dengan angka 3 disertai digit keduanya yakni 1 dan 3), maka tes tiga digit pertama cenderung untuk mengidentifikasi jumlah deret angkan yang tidak biasa dan telah digandakan.

Fungsi kedua pengujian, tes dua digit pertama dan tiga digit pertama adalah untuk mencari pola digit yang terlalu sering digunakan, yang mana hal ini mengindikasikan penipuan, atau adanya data yang salah diinput, atau bahkan proses penggandaan faktur yang sama untuk digunakan sebagai bukti dokumen di beberapa transaksi.

\section{v. Tes Dua Digit Terakhir}

Tes dua digit terakhir digunakan untuk mengidentifikasi angkaangka yang dibuat-buat dan dibulatkan. Tes ini sangat berguna karena mungkin para auditor perlu memilih target audit dalam populasi yang lebih kecil misalnya kurang dari 10.000. Dikarenakan proporsi yang diharapkan dari Hukum Benford untuk semua kombinasi dua digit terakhir adalah 0,01 , maka cukup mudah untuk mengidentifikasi kelainan melalui grafik. Tes ini sangat berguna jika angka-angka laporan keuangan telah bulat, dengan demikian menunjukkan bahwa angka-angka tersebut adalah perkiraan dan bukan jumlah aktual. Karena tes ini menghasilkan ukuran sampel yang kecil dan efisien, maka dapat digunakan untuk mengidentifikasi pola yang mungkin tidak terbukti saat menggunakan empat tes sebelumnya.

\section{Metode Statistik}

Seperti yang dinyatakan sebelumnya di atas, tes digit pertama dan digit kedua adalah tes dengan tingkat yang paling sederhana dan dapat digunakan untuk menilai kewajaran sebaran frekuensi data secara umum yang dibandingkan dengan kurva Benford, tetapi kedua tes ini tidak bisa digunakan untuk memilih sampel audit. Selanjutnya jika kemudian kedua tes ini menunjukkan bahwa data secara signifikan berbeda dari kurva Benford, maka pemeriksaan harus dilanjutkan dengan tahap pengujian dua digit pertama dan tes tiga digit pertama untuk memilih target audit. Tes dua digit terakhir juga dapat digunakan sebagai tambahan untuk mendeteksi adanya pembulatan angka secara artifisial. 
Tetapi bagaimana cara untuk memastikan apakah sebaran frekuensi sekumpulan data yang akan diaudit telah sesuai dengan Hukum Benford? Terkadang beberapa digit akan secara signifikan lebih besar penyimpangannya dibandingkan dengan proporsi frekuensi yang diharapkan, dan tidak ada tambahan pengujian yang diperlukan. Namun, kadang-kadang tidak jelas digit mana yang secara statistik bernilai signifikan. Dalam hal ini, auditor perlu menggunakan metode empiris untuk menentukan digit mana yang akan menjadi fokus perhatian mereka. Berikut ini merupakan beberapa pilihan metode statistik dalam menentukan besaran penyimpangan yang cukup signifikan.

\section{Z-Statistic}

Pengujian empiris pertama yang dapat dilakukan dengan menggunakan metode Z-Statistic. Ini adalah pengujian dua arah, dengan tingkat $\alpha=10 \%$ dan formula perhitungan menggunakan rumus sebagai berikut:

$$
Z=\frac{\text { I po }- \text { pe I - (1/2n) }}{\sqrt{\left(p^{*} *(1-p e) / n\right)}}
$$

Apabila nilai Z-Statistic yang dihasilkan dari pengujian mencapai hingga lebih dari 1.65 maka hal ini merupakan indikasi empiris yang menunjukan adanya penyimpangan data yang signifikan sehingga perlu dilakukan pemeriksaan lebih jauh.

\section{Chi-square Test}

Jika pada pengujian empiris sebelumnya bertujuan untuk menguji signifikansi nilai deviasi data dengan menggunakan z-statistic, maka perlu diuji kembali tingkat penyebaran deviasi tersebut. Melalui metode chi-square test, tingkat penyebaran penyimpangan yang dialami dalam sebuah sampel data dapatlah diukur. Dengan demikian akan terjawab secara empiris pertanyaan apakah penyebaran penyimpangannya cukup signifikan sehingga mengandung fraud ataukah pola penyebaran deviasinya masih berada dalam tingkat kewajaran.

$$
\text { Chi-square }=\sum(\mathrm{AC}-\mathrm{EC})^{2} / \mathrm{EC}
$$

\section{Mean Absolute Deviation (MAD)}

Secara garis besar, MAD ditujukan untuk menghitung rata-rata dari nilai absolute perbedaan antara proporsi aktual dengan proporsi Hukum Benford.

Perbedaan absolute kemudian dijumlah dan dibagi dengan banyaknya sampel. Setelah itu barulah cut-off value dihitung sebagai threshold untuk menentukan signifikansinya, di mana menurut Nigrini (2000) ambang batas yang disarankan adalah sebagai berikut:

1. MAD : $0.000-0.004$ "Close Conformity"

2. MAD : $0.004-0.008$ "Acceptable Conformity"

3. MAD : $0.008-0.012$ "Marginally Acceptable Conformity"

4. MAD :> 0.012 "Non-conformity"

\section{Hasil dan Pembahasan}

Analisa akan diawali dengan pengujian yang paling sederhana, di mana dengan ketentuan tingkat confidence level sebesar 0.10 maka data dengan nilai Zstatistics yang lebih besar dari 1.65 mengindikasikan penyimpangan yang signifikan dari sebaran Hukum Benford Tes Digit Pertama. Pada tabel dan grafik berikut ini dapat dilihat bagaimana perolehan hasil pengujian yang dilakukan pada Laporan Keuangan PT Garuda Indonesia (Persero) Tbk. Tahun 2018. 
Tabel 4. Perhitungan Penyimpangan Proporsi Data Laporan Keuangan PT Garuda Indonesia (Persero) Tbk. Tahun 2018 pada Tes Digit Pertama

\begin{tabular}{ccccccc}
$\begin{array}{c}\text { 1st } \\
\text { Digit }\end{array}$ & $\begin{array}{c}\text { Count } \\
\text { from Data }\end{array}$ & $\%$ & Benford's Law & Difference & Chi-Square & Abs \\
1 & 30 & 0.26087 & 0.301029996 & -0.04016043 & 0.005357806 & 0.04016043 \\
2 & 22 & 0.191304 & 0.176091259 & 0.015213089 & 0.001314308 & 0.015213089 \\
3 & 17 & 0.147826 & 0.124938737 & 0.02288735 & 0.004192701 & 0.02288735 \\
4 & 14 & 0.121739 & 0.096910013 & 0.024829117 & 0.006361418 & 0.024829117 \\
5 & 6 & 0.052174 & 0.079181246 & -0.027007333 & 0.009211727 & 0.027007333 \\
6 & 9 & 0.078261 & 0.06694679 & 0.01131408 & 0.001912092 & 0.01131408 \\
7 & 8 & 0.069565 & 0.057991947 & 0.01157327 & 0.002309641 & 0.01157327 \\
8 & 3 & 0.026087 & 0.051152522 & -0.025065566 & 0.012282534 & 0.025065566 \\
9 & 6 & 0.052174 & 0.045757491 & 0.006416422 & 0.000899754 & 0.006416422 \\
SUM & 115 & & & & $\mathbf{0 . 0 4 3 8 4 1 9 8}$ & 0.184466659 \\
& & & & & & 0.001604058 \\
\hline
\end{tabular}

Sumber : Hasil olahan penulis

Tabel 4. (Lanjutan)

\begin{tabular}{ccccc|}
\hline $\mathbf{1 / 2 N}$ & Numerator & Denominator & SQRT of Denom & Z Statistic \\
0.004347826 & 0.035812604 & 0.00182966 & 0.042774529 & 0.83724135 \\
0.004347826 & 0.010865263 & 0.001261592 & 0.035518902 & 0.305900859 \\
0.004347826 & 0.018539524 & 0.000950687 & 0.030833219 & 0.601284102 \\
0.004347826 & 0.020481291 & 0.00076103 & 0.027586774 & 0.742431545 \\
0.004347826 & 0.022659507 & 0.000634014 & 0.025179629 & 0.899914256 \\
0.004347826 & 0.006966254 & 0.000543173 & 0.023306076 & 0.298902903 \\
0.004347826 & 0.007225444 & 0.000475034 & 0.021795269 & 0.331514346 \\
0.004347826 & 0.02071774 & 0.000422052 & 0.020543896 & 1.008462061 \\
0.004347826 & 0.002068596 & 0.000379685 & 0.0194855 & 0.106160805
\end{tabular}

Sumber : Hasil olahan penulis

Grafik 3. Penyimpangan Proporsi Data Laporan Keuangan PT Garuda Indonesia (Persero)

Tbk. Tahun 2018 pada Tes Digit Pertama

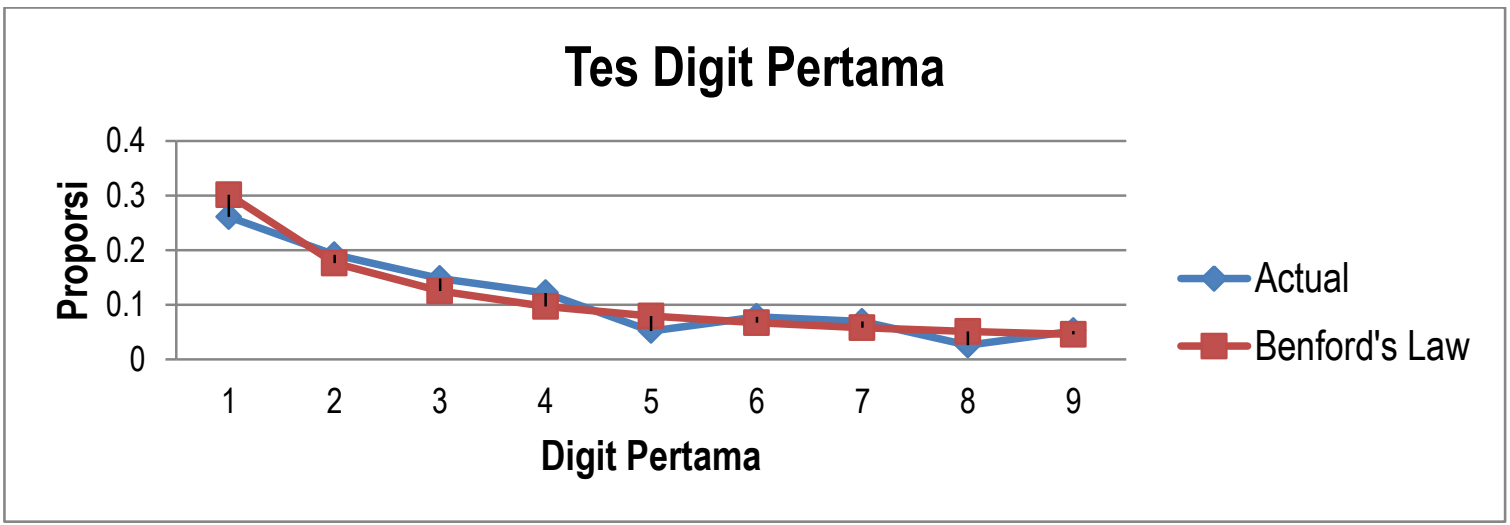


Seperti yang tergambarkan dalam grafik di atas, tidak ada penyimpangan yang signifikan atas proporsi data laporan keuangan PT Garuda Indonesia (Persero) Tbk. Tahun 2018 pada Tes Digit Pertama. Hampir seluruh digit pertama (angka $1 \mathrm{~s} / \mathrm{d}$ 9) mengikuti pola sebaran Hukum Benford. Hal ini juga didukung dengan bukti empiris (Tabel 4) yang menunjukan nilai rata-rata perbedaan absolut (MAD) sebesar 0.001604058 , yang artinya adalah "Close Conformity" atau dengan kata lain distribusi populasi mengikuti Hukum Benford. Sementara itu, perhitungan ZStatistic pada masing-masing digit juga mendukung hal tersebut yakni dengan berada di bawah nilai cutoff sebesar 1.65 poin. Dikarenakan pengujian pada Tes Digit Pertama tidak memberikan hasil penyimpangan yang signifikan maka pengolahan data tidak perlu dilanjutkan ke tingkat berikutnya (Tes Dua Digit Pertama, Tes Tiga Digit Pertama dan Tes Dua Digit Terakhir). Seperti yang telah diterangkan sebelumnya di atas, pengujian-pengujian tersebut barulah akan diperlukan untuk mengarahkan fokus penyelidikan (audit) jika ditemukan adanya penyimpangan yang cukup dominan pada digit pertama. Walaupun demikian, pengujian dapat terus dilanjutkan dengan melihat pola penyimpangan data laporan keuangan PT Garuda Indonesia melalui Tes Digit Kedua, Tes Digit Ketiga dan Tes Digit Keempat. Pada tabel dan grafik berikut ini dapat dilihat bagaimana perolehan hasil pengujian yang dilakukan pada Laporan Keuangan PT Garuda Indonesia (Persero) Tbk. Tahun 2018 untuk Tes Digit Kedua.

Tabel 5. Perhitungan Penyimpangan Proporsi Data Laporan Keuangan PT Garuda Indonesia (Persero) Tbk. Tahun 2018 pada Tes Digit Kedua

\begin{tabular}{ccccccc} 
2nd Digit & $\begin{array}{c}\text { Count from } \\
\text { Data }\end{array}$ & $\%$ & $\begin{array}{c}\text { Benford's } \\
\text { Law }\end{array}$ & Difference & \multicolumn{1}{c}{$\begin{array}{c}\text { Chi- } \\
\text { Square }\end{array}$} & \multicolumn{1}{c}{ Abs } \\
\hline 0 & 10 & 0.088496 & 0.11968 & -0.031184425 & 0.008125571 & 0.031184425 \\
1 & 17 & 0.150442 & 0.11389 & 0.036552478 & 0.011731352 & 0.036552478 \\
2 & 16 & 0.141593 & 0.10882 & 0.03277292 & 0.0098701 & 0.03277292 \\
3 & 17 & 0.150442 & 0.10433 & 0.046112478 & 0.020381104 & 0.046112478 \\
4 & 10 & 0.088496 & 0.10331 & -0.014814425 & 0.002124356 & 0.014814425 \\
5 & 9 & 0.079646 & 0.09668 & -0.017033982 & 0.003001206 & 0.017033982 \\
6 & 13 & 0.115044 & 0.09337 & 0.021674248 & 0.005031306 & 0.021674248 \\
7 & 8 & 0.070796 & 0.09035 & -0.01955354 & 0.004231776 & 0.01955354 \\
8 & 6 & 0.053097 & 0.08757 & -0.034472655 & 0.013570446 & 0.034472655 \\
9 & 7 & 0.061947 & 0.085 & -0.023053097 & 0.006252298 & 0.023053097 \\
SUM & 113 & & & & 0.084319513 & 0.277224248
\end{tabular}

Sumber : Hasil olahan penulis 
Tabel 5. (Lanjutan)

\begin{tabular}{ccccr}
$\mathbf{1} / 2 \mathbf{N}$ & Numerator & Denominator & $\begin{array}{c}\text { SQRT of } \\
\text { Denom }\end{array}$ & \multicolumn{1}{l}{ Z Statistic } \\
\hline 0.004424779 & 0.026759646 & 0.00093236 & 0.030534573 & 0.876372036 \\
0.004424779 & 0.032127699 & 0.000893089 & 0.029884596 & 1.075058829 \\
0.004424779 & 0.028348142 & 0.000858214 & 0.029295294 & 0.9676688 \\
0.004424779 & 0.041687699 & 0.000826949 & 0.028756723 & 1.449667924 \\
0.004424779 & 0.010389646 & 0.000819797 & 0.028632095 & 0.362867129 \\
0.004424779 & 0.012609204 & 0.000772858 & 0.027800327 & 0.453563129 \\
0.004424779 & 0.017249469 & 0.000749133 & 0.027370296 & 0.630225876 \\
0.004424779 & 0.015128761 & 0.000727318 & 0.026968825 & 0.560972207 \\
0.004424779 & 0.030047876 & 0.000707093 & 0.026591218 & 1.129992468 \\
0.004424779 & 0.018628319 & 0.000688274 & 0.026234983 & 0.710056436
\end{tabular}

Sumber : Hasil olahan penulis

Grafik 4. Penyimpangan Proporsi Data Laporan Keuangan PT Garuda Indonesia (Persero)

Tbk. Tahun 2018 pada Tes Digit Kedua

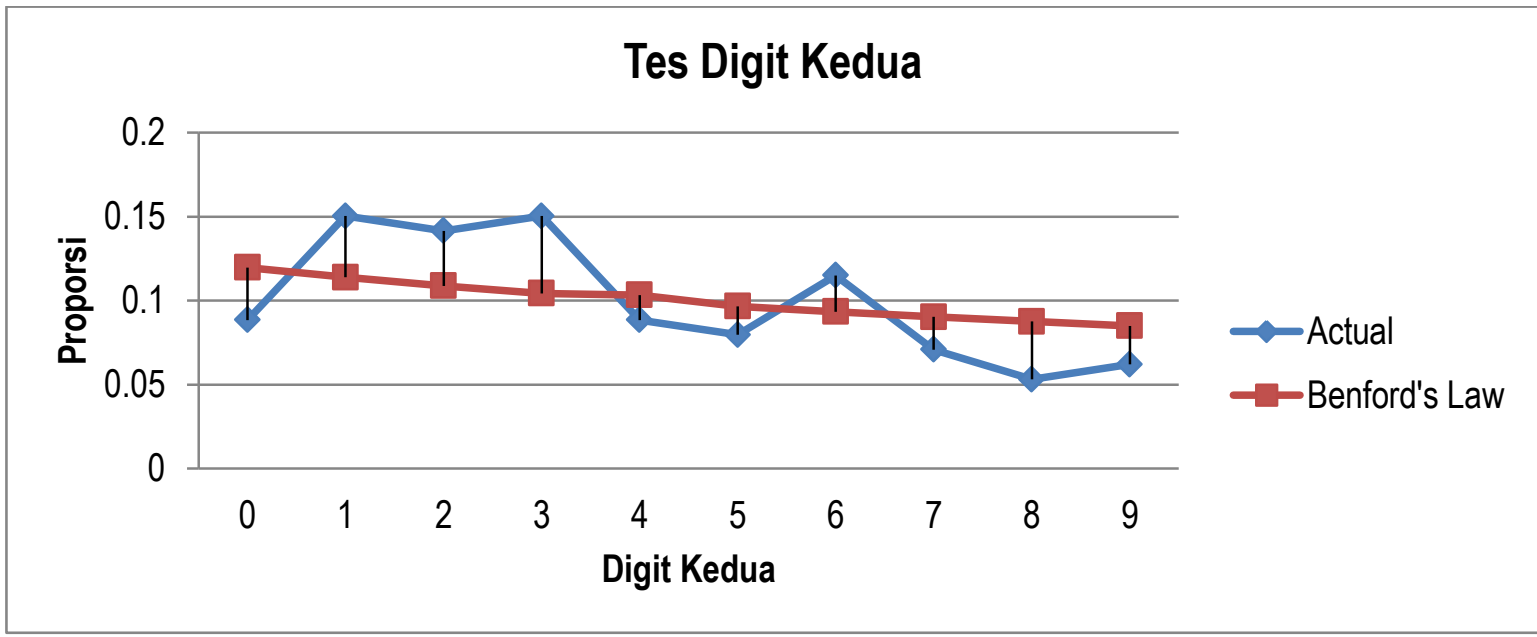

Dapat dilihat pada grafik di atas, mulai nampak adanya penyimpangan (pada angka 1, 2, 3, dan 8 untuk digit kedua) atas proporsi data laporan keuangan PT Garuda Indonesia (Persero) Tbk. Tahun 2018. Namun walaupun demikian, jarak penyimpangan yang tergambarkan dalam grafik ternyata tidak cukup signifikan. Hal ini didukung dengan bukti statistik (Tabel 5) yang menunjukan nilai rata-rata perbedaan absolut (MAD) antara data aktual dengan Hukum Benford hanyalah sebesar 0.002453312 , yang artinya adalah "Close Conformity" atau dengan kata lain distribusi populasi mengikuti pola Hukum Benford. Sedangkan untuk hasil perhitungan Z-Statistic pada masingmasing digit juga tidak jauh berbeda yakni dengan berada di bawah nilai cutoff sebesar 1.65 poin, yang artinya adalah tidak ada data keuangan yang sebarannya tidak mengikuti konsep probabilitas kemunculan angka Hukum Benford. 
Pengujian kemudian dilanjutkan ke model Tes Digit Ketiga, dengan perolehan hasil terdapat perbedaan yang signifikan pada angka 2 (dua). Di mana nilai Mean Absolute Deviation yang diperoleh khusus untuk angka 2 (dua) adalah sebesar 0.056722212 dan berindikasi "Nonconformity" yang artinya distribusi populasi angka 2 (dua) pada digit ketiga tidak mengikuti pola Hukum Benford. Sementara itu, hasil perhitungan Z-Statistic juga mendukung temuan ini yakni dengan berada di atas ambang batas ketentuan tingkat confidence level $10 \%$ sebesar 1.845169762. Jika merujuk pada data laporan keuangan PT Garuda Indonesia (Persero) Tbk. Tahun 2018., maka dapat dilihat bahwa akun-akun yang nilai nominalnya mengandung angka 2 (dua) pada digit ketiga; di antaranya adalah Pajak Dibayar Dimuka (Kelompok Aset Lancar) serta Uang Muka Pembelian Peswat
(Kelompok Aset Tidak Lancar). Kedua akun tersebut masing-masing memiliki porsi kurang dari 1\% Total Aset untuk Pajak Dibayar Dimuka dan porsi yang lebih besar dari 4\% Total Aset untuk Uang Muka Pembelian Pesawat, di mana kondisi ini yang akhirnya menyebabkan akun-akun tersebut menjadi tidak material untuk ditinjau lebih lanjut. Hal ini dikarenakan menurut Mihkel Tammaru dan Lehte Alver (2016), seorang auditor akan mengganggap sebuah akun bersifat material serta memiliki resiko audit yang tinggi jika berada dalam jangkauan nilai $1 \%$ hingga $2 \%$ dari total aset. Berikut ini tampilan tabel perhitungan dan grafik untuk perolehan hasil pengujian yang dilakukan pada Laporan Keuangan PT Garuda Indonesia (Persero) Tbk. Tahun 2018 untuk Tes Digit Ketiga.

Tabel 6. Perhitungan Penyimpangan Proporsi Data Laporan Keuangan PT Garuda Indonesia (Persero) Tbk. Tahun 2018 pada Tes Digit Ketiga

\begin{tabular}{|c|c|c|c|c|c|c|c|}
\hline 3rd Digit & & $\begin{array}{c}\text { Count } \\
\text { from Data }\end{array}$ & $\%$ & $\begin{array}{c}\text { Benford's } \\
\text { Law }\end{array}$ & Difference & Chi-Square & Abs \\
\hline & 0 & 15 & 0.132743 & 0.10178 & 0.030963363 & 0.009419629 & 0.030963363 \\
\hline & 1 & 13 & 0.115044 & 0.10138 & 0.013664248 & 0.001841701 & 0.013664248 \\
\hline & 2 & 5 & 0.044248 & 0.10097 & -0.056722212 & 0.031865003 & 0.056722212 \\
\hline & 3 & 11 & 0.097345 & 0.10057 & -0.003224867 & 0.000103408 & 0.003224867 \\
\hline & 4 & 12 & 0.106195 & 0.10018 & 0.00601469 & 0.000361115 & 0.00601469 \\
\hline & 5 & 13 & 0.115044 & 0.09979 & 0.015254248 & 0.002331818 & 0.015254248 \\
\hline & 6 & 11 & 0.097345 & 0.0994 & -0.002054867 & 4.24797E-05 & 0.002054867 \\
\hline & 7 & 10 & 0.088496 & 0.09902 & -0.010524425 & 0.001118597 & 0.010524425 \\
\hline & 8 & 12 & 0.106195 & 0.09864 & 0.00755469 & 0.000578602 & 0.00755469 \\
\hline & 9 & 11 & 0.097345 & 0.09827 & -0.000924867 & $8.70438 \mathrm{E}-06$ & 0.000924867 \\
\hline & & & & & & 0.04767105 & 0.14690247 \\
\hline SUM & & 113 & & & & 3 & 8 \\
\hline
\end{tabular}


Tabel 6. (Lanjutan)

\begin{tabular}{rrrrr}
\multicolumn{1}{l}{$1 / 2 \mathrm{~N}$} & Numerator & Denominator & \multicolumn{1}{c}{$\begin{array}{c}\text { SQRT of } \\
\text { Denom }\end{array}$} & Z Statistic \\
\hline 0.004424779 & 0.026538584 & 0.000809034 & 0.028443521 & 0.933027375 \\
0.004424779 & 0.009239469 & 0.000806213 & 0.028393894 & 0.325403374 \\
0.004424779 & 0.052297434 & 0.000803319 & 0.028342885 & $\mathbf{1 . 8 4 5 1 6 9 7 6 2}$ \\
0.004424779 & -0.001199912 & 0.000800493 & 0.02829298 & -0.04241022 \\
0.004424779 & 0.001589912 & 0.000797734 & 0.028244189 & 0.056291632 \\
0.004424779 & 0.010829469 & 0.000794973 & 0.028195267 & 0.384088193 \\
0.004424779 & -0.002369912 & 0.000792209 & 0.028146211 & -0.084200019 \\
0.004424779 & 0.006099646 & 0.000789514 & 0.028098285 & 0.217082502 \\
0.004424779 & 0.003129912 & 0.000786815 & 0.028050232 & 0.111582377 \\
0.004424779 & -0.003499912 & 0.000784186 & 0.02800332 & -0.124982022
\end{tabular}

Sumber : Hasil olahan penulis

Grafik 5. Penyimpangan Proporsi Data Laporan Keuangan PT Garuda Indonesia (Persero) Tbk. Tahun 2018 pada Tes Digit Ketiga

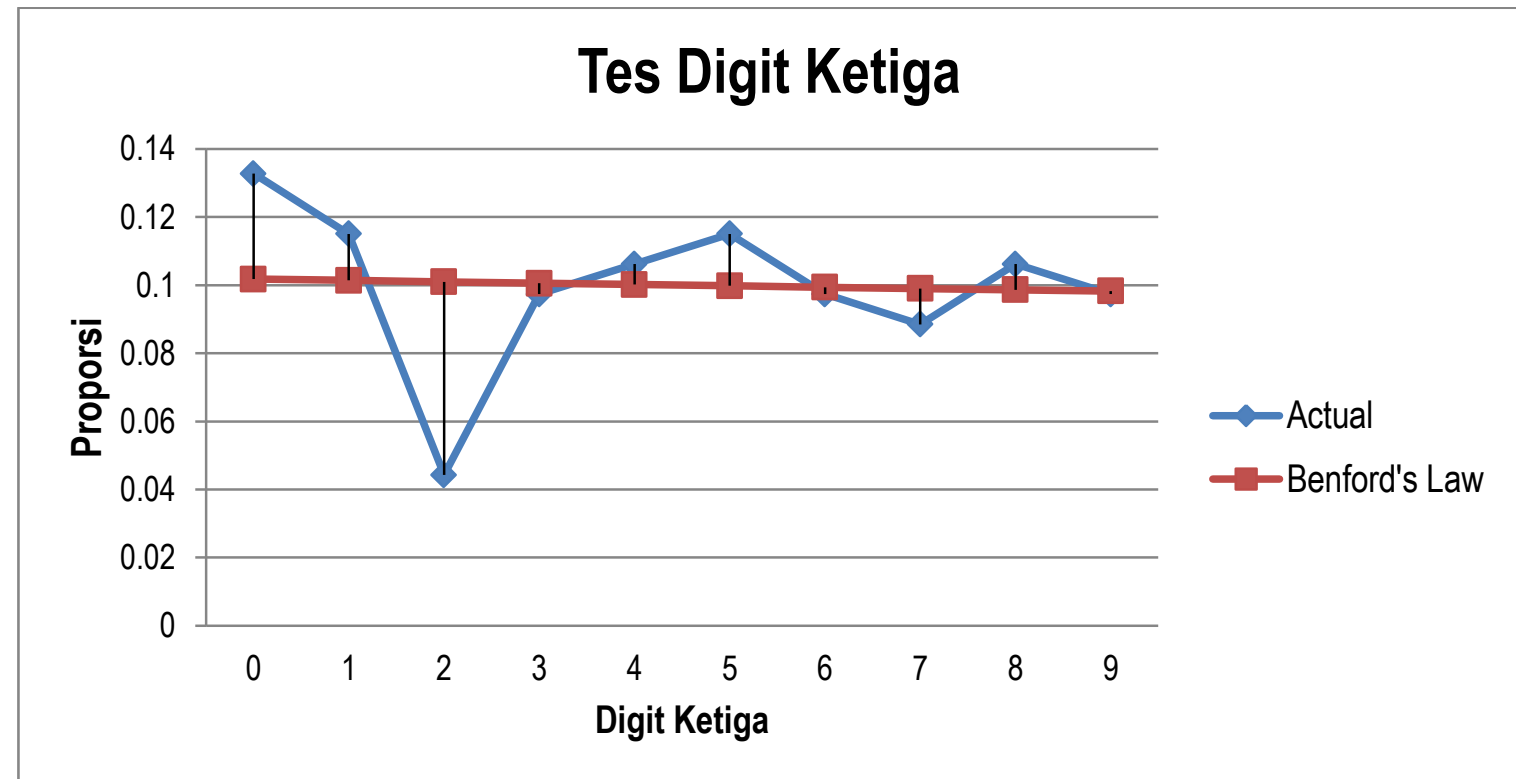

Sedangkan untuk model Tes Digit Keempat, hasil yang diperoleh sama seperti hasil Tes Digit Pertama dan Tes Digit Kedua, di mana tidak terdapat penyimpangan yang signifikan atas proporsi data laporan keuangan PT Garuda Indonesia (Persero) Tbk. Tahun 2018 jika dibandingkan dengan Hukum Benford. Sebaran data pada pengujian Tes Digit Keempat agak menonjol di angka 4 (empat) dan penyimpangan yang terjadi adalah kurangnya nilai akun yang menganduang angka 4 pada digit keempat. Namun penyimpangan ini dinilai masih tidak cukup signifikan setelah melewati uji empiris, dengan perolehan nilai rata-rata perbedaan absolut (MAD) antara data aktual dengan Hukum Benford adalah sebesar 0.001354798 yang mengindikasikan "Close Conformity" atau dengan kata lain distribusi populasi mengikuti pola Hukum Benford. Sedangkan untuk hasil 
perhitungan Z-Statistic pada masing-masing digit juga berada di bawah nilai cutoff sebesar 1.65 poin, yang artinya adalah tidak ada nilai akun yang sebarannya tidak mengikuti konsep probabilitas kemunculan angka Hukum Benford. Berikut ini tampilan tabel perhitungan dan grafik untuk perolehan hasil pengujian yang dilakukan pada Laporan Keuangan PT Garuda Indonesia (Persero) Tbk. Tahun 2018 untuk Tes Digit Keempat.

Tabel 7. Perhitungan Penyimpangan Proporsi Data Laporan Keuangan PT Garuda Indonesia (Persero) Tbk. Tahun 2018 pada Tes Digit Keempat

\begin{tabular}{|c|c|c|c|c|c|c|}
\hline $\begin{array}{l}\text { 4th } \\
\text { Digit }\end{array}$ & $\begin{array}{c}\text { Count } \\
\text { from Data }\end{array}$ & $\%$ & Benford's Law & Difference & Chi-Square & Abs \\
\hline 0 & 13 & 0.113043 & 0.10018 & 0.012863478 & 0.001651718 & 0.012863478 \\
\hline 1 & 14 & 0.121739 & 0.10014 & 0.02159913 & 0.004658702 & 0.02159913 \\
\hline 2 & 13 & 0.113043 & 0.1001 & 0.012943478 & 0.001673663 & 0.012943478 \\
\hline 3 & 14 & 0.121739 & 0.10006 & 0.02167913 & 0.004697029 & 0.02167913 \\
\hline 4 & 7 & 0.06087 & 0.10002 & -0.039150435 & 0.015324501 & 0.039150435 \\
\hline 5 & 12 & 0.104348 & 0.09998 & 0.004367826 & 0.000190817 & 0.004367826 \\
\hline 6 & 10 & 0.086957 & 0.09994 & -0.012983478 & 0.001686719 & 0.012983478 \\
\hline 7 & 12 & 0.104348 & 0.0999 & 0.004447826 & 0.00019803 & 0.004447826 \\
\hline 8 & 10 & 0.086957 & 0.09986 & -0.012903478 & 0.001667332 & 0.012903478 \\
\hline 9 & 10 & 0.086957 & 0.09982 & -0.012863478 & 0.001657675 & 0.012863478 \\
\hline \multirow[t]{2}{*}{ SUM } & 115 & & & & 0.033406184 & 0.155801739 \\
\hline & & & & MAD & & 0.001354798 \\
\hline
\end{tabular}

Sumber : Hasil olahan penulis

Tabel 7. (Lanjutan)

\begin{tabular}{crrrr}
$1 / 2 \mathrm{~N}$ & Numerator & Denominator & \multicolumn{1}{l}{$\begin{array}{l}\text { SQRT of } \\
\text { Denom }\end{array}$} & \multicolumn{1}{l}{ Z Statistic } \\
\hline 0.004347826 & 0.008515652 & 0.000783861 & 0.02799751 & 0.304157479 \\
0.004347826 & 0.017251304 & 0.000783582 & 0.027992543 & 0.616282152 \\
0.004347826 & 0.008595652 & 0.000783304 & 0.027987573 & 0.307123882 \\
0.004347826 & 0.017331304 & 0.000783026 & 0.027982603 & 0.619359983 \\
0.004347826 & 0.034802609 & 0.000782748 & 0.027977631 & 1.2439441 \\
0.004347826 & $2 \mathrm{E}-05$ & 0.00078247 & 0.027972657 & 0.000714984 \\
0.004347826 & 0.008635652 & 0.000782191 & 0.027967683 & 0.308772532 \\
0.004347826 & $1 \mathrm{E}-04$ & 0.000781913 & 0.027962707 & 0.003576192 \\
0.004347826 & 0.008555652 & 0.000781635 & 0.027957729 & 0.306020999 \\
0.004347826 & 0.008515652 & 0.000781356 & 0.02795275 & 0.304644521
\end{tabular}


Sumber : Hasil olahan Penulis

Grafik 6. Penyimpangan Proporsi Data Laporan Keuangan PT Garuda Indonesia (Persero)

Tbk. Tahun 2018 pada Tes Digit Keempat

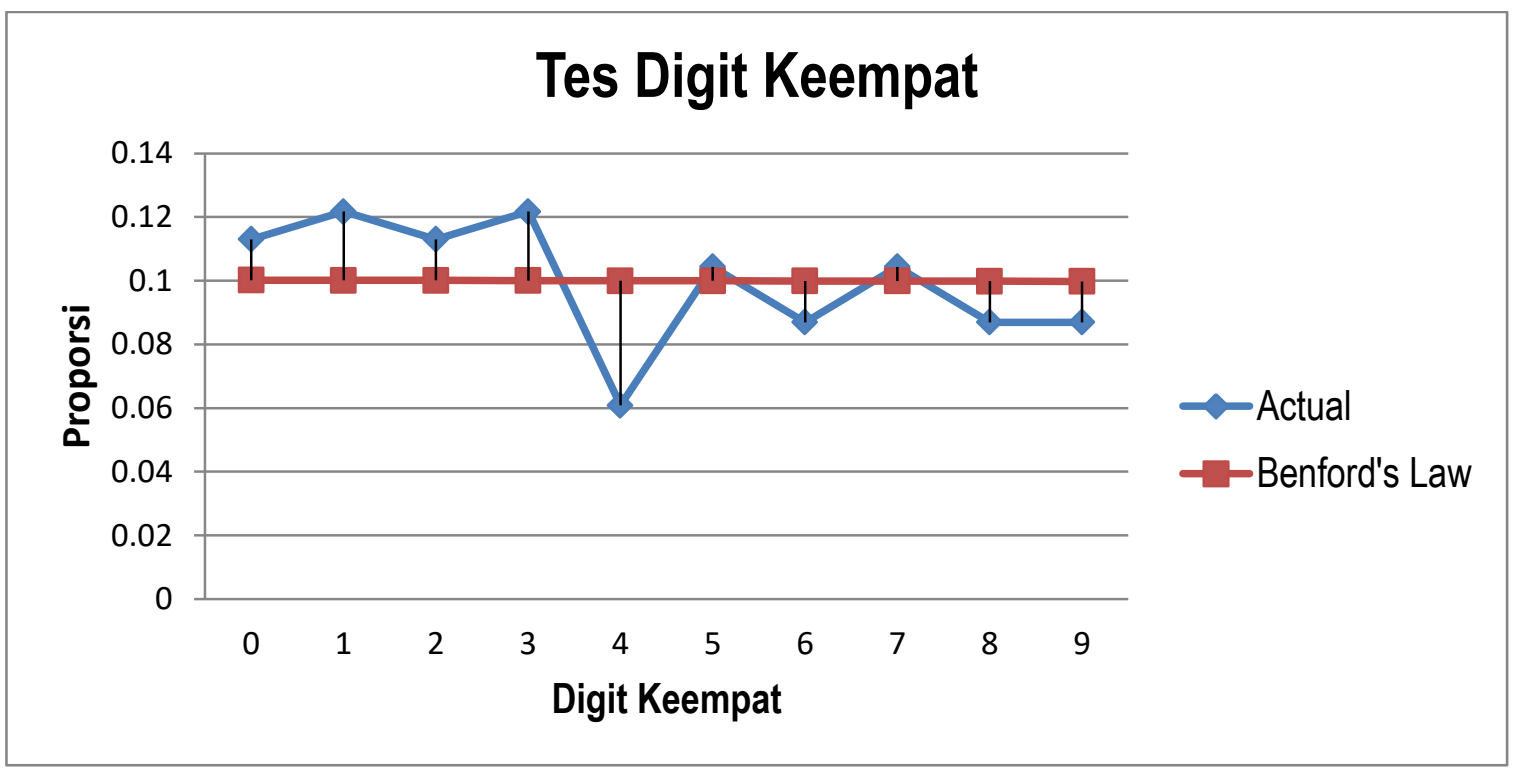

Setelah melewati keempat model pengujian seperti yang dipaparkan sebelumnya di atas, maka dapat disimpulkan bahwa sebaran data keuangan pada laporan keuangan PT Garuda Indonesia (Persero) Tbk. Tahun 2018 tidak mengalami penyimpangan yang signifikan jika dibandingkan dengan Hukum Benford., atau dengan kata lain distribusi populasi mengikuti pola Hukum Benford. Pengujian ini dilakukan atas 113 115 buah akun yang dilaporkan pada keempat laporan keuangan Garuda Indonesia; dengan ditemukan beberapa akun di antaranya yang berhasil terdeteksi mengalami penyimpangan pada model pengujian Tes Digit Kedua namun akunakun tersebut diabaikan karna tidak mengandung resiko audit yang material.

Walaupun hasil penelitian belum berhasil menjawab tujuan dari kajian ilmiah ini namun sebenarnya pemaparan fenomena di atas, sekali lagi, telah menguatkan posisi konsep Probabilitas Hukum Benford di bidang penelitian Akuntansi. Hal ini dikarenakan Laporan Keuangan PT Garuda Indonesia (Persero) Tbk. Tahun 2018 telah mengalami restatement atau penyajian ulang kembali sesuai dengan Surat Otoritas Jasa Keuangan No. S-21/PM.1/2019 perihal sanksi administratif atas pelanggaran peraturan perundang-undangan di bidang pasar modal tertanggal 28 Juni 2019. Oleh karena itu dapat disimpulkan bahwa Laporan Keuangan PT Garuda Indonesia (Persero) Tbk. Tahun 2018 telah benar adanya sehingga tidaklah mengherankan jika distribusi populasi akun-akunnya juga mengikuti pola Hukum Benford.

Meskipunn demikian, kajian penelitian akan dilanjutkan dengan turut menilai kondisi laporan keuangan pada tahun sebelumnya. Mengapa ini perlu dilakukan, karena pada prinsip akuntansi terkandung pedoman bahwa dalam penyusunan laporan keuangan, saldo akhir sebuah akun saat penutupan tahun buku akan menjadi saldo awal bagi akun tersebut, contoh saldo akhir Kas dan Setara Kas tahun 2017 menjadi saldo awal Kas dan Setara Kas tahun 2018 (Weygandt et. al 2018). Berdasarkan prinsip inilah maka tidak salah jika analisa penelitian akan dibawa mundur ke periode sebelumnya untuk melihat apakah terdapat kemungkinan distribusi populasi akun-akun 
yang tidak mengikuti pola Hukum Benford dan akun-akun tersebut masuk dalam daftar pilihan akun yang di-restated oleh Garuda pada tahun 2018. Berikut ini tampilan tabel perhitungan untuk perolehan hasil

Tabel 8. Perhitungan Penyimpangan Proporsi Data Laporan Keuangan PT Garuda Indonesia pengujian yang dilakukan pada Laporan Keuangan PT Garuda Indonesia (Persero) Tbk. Tahun 2017 untuk Tes Digit Pertama.

(Persero) Tbk. Tahun 2017 pada Tes Digit Pertama

\begin{tabular}{ccccrrrr|}
\hline $\begin{array}{c}\text { 1st } \\
\text { Digit }\end{array}$ & $\begin{array}{c}\text { Count } \\
\text { from Data }\end{array}$ & $\%$ & Benford's Law & Difference & \multicolumn{1}{c|}{ Diff^2 } & Comp. Chi 2 & \multicolumn{1}{c|}{ Abs } \\
\hline 1 & 29 & 0.243697 & 0.301029996 & -0.05733 & 0.003287 & 0.010919236 & 0.0573325 \\
2 & 21 & 0.176471 & 0.176091259 & 0.000379 & $1.44 \mathrm{E}-07$ & $8.17137 \mathrm{E}-07$ & 0.0003793 \\
3 & 16 & 0.134454 & 0.124938737 & 0.009515 & $9.05 \mathrm{E}-05$ & 0.000724644 & 0.009515 \\
4 & 21 & 0.176471 & 0.096910013 & 0.079561 & 0.00633 & 0.065317143 & 0.0795606 \\
5 & 9 & 0.07563 & 0.079181246 & -0.00355 & $1.26 \mathrm{E}-05$ & 0.000159249 & 0.003551 \\
6 & 9 & 0.07563 & 0.06694679 & 0.008683 & $7.54 \mathrm{E}-05$ & 0.001126305 & 0.0086835 \\
7 & 2 & 0.016807 & 0.057991947 & -0.04119 & 0.001696 & 0.02924928 & 0.0411852 \\
8 & 5 & 0.042017 & 0.051152522 & -0.00914 & $8.35 \mathrm{E}-05$ & 0.001631617 & 0.0091357 \\
9 & 7 & 0.058824 & 0.045757491 & 0.013066 & 0.000171 & 0.003731004 & 0.013066 \\
SUM & 119 & & & & & 0.112859294 & 0.2224089 \\
\hline
\end{tabular}

Sumber : Hasil olahan Penulis

Tabel 8. (Lanjutan)

\begin{tabular}{lrrrrr}
\hline $1 / 2 \mathrm{~N}$ & Numerator & Denominator & SQRT of Denom & Z Statistic & Z Score 99\% \\
0.004202 & 0.05313084 & 0.001768159 & 0.042049484 & 1.263531 & \\
0.004202 & -0.0038224 & 0.001219186 & 0.034916843 & -0.10947 & \\
0.004202 & 0.00531336 & 0.000918732 & 0.030310584 & 0.175297 & \\
0.004202 & 0.07535889 & 0.000735449 & 0.027119168 & $\mathbf{2 . 7 7 8 8 0 6}$ & $\mathbf{2 . 5 8}$ \\
0.004202 & -0.0006507 & 0.000612702 & 0.024752825 & -0.02629 & \\
0.004202 & 0.00448178 & 0.000524915 & 0.022911029 & 0.195617 & \\
0.004202 & 0.03698354 & 0.000459066 & 0.021425831 & 1.726119 & \\
0.004202 & 0.00493404 & 0.000407865 & 0.020195669 & 0.244312 & \\
0.004202 & 0.00886436 & 0.000366922 & 0.019155214 & 0.462765 &
\end{tabular}

Sumber : Hasil olahan Penulis

Seperti yang dipaparkan dalam tabel di atas, terdapat salah satu penyimpangan yang signifikan atas proporsi data laporan keuangan PT Garuda Indonesia (Persero) Tbk. Tahun 2017 pada Tes Digit Pertama. Hampir seluruh digit pertama (angka $1 \mathrm{~s} / \mathrm{d}$ 9) mengikuti pola sebaran Hukum Benford, kecuali untuk angka 4. Hal ini juga didukung dengan bukti empiris yang menunjukan nilai perbedaan absolut (MAD) untuk angka 4 (empat) pada digit pertama adalah sebesar 0.0795606, yang artinya mendekati "Marginally Acceptable Conformity" atau dengan kata lain 
distribusi populasi hampir mendekati ambang batas untuk dinyatakan tidak mengikuti Hukum Benford. Sementara itu, perhitungan Z-Statistic pada angka 4 digit pertama juga mendukung hal tersebut yakni dengan berada di atas nilai cutoff bahkan untuk batas ketentuan dengan tingkat $\alpha$ paling tinggi (confidence level 99\%) sebesar 2.778806 yang lebih tinggi dari 2.58. Sedangkan untuk sebaran populasi data dalam tabel perhitungan di atas dapat dilihat dalam penyajian grafik berikut ini:

Grafik 7. Penyimpangan Proporsi Data Laporan Keuangan PT Garuda Indonesia (Persero)

Tbk. Tahun 2017 pada Tes Digit Pertama

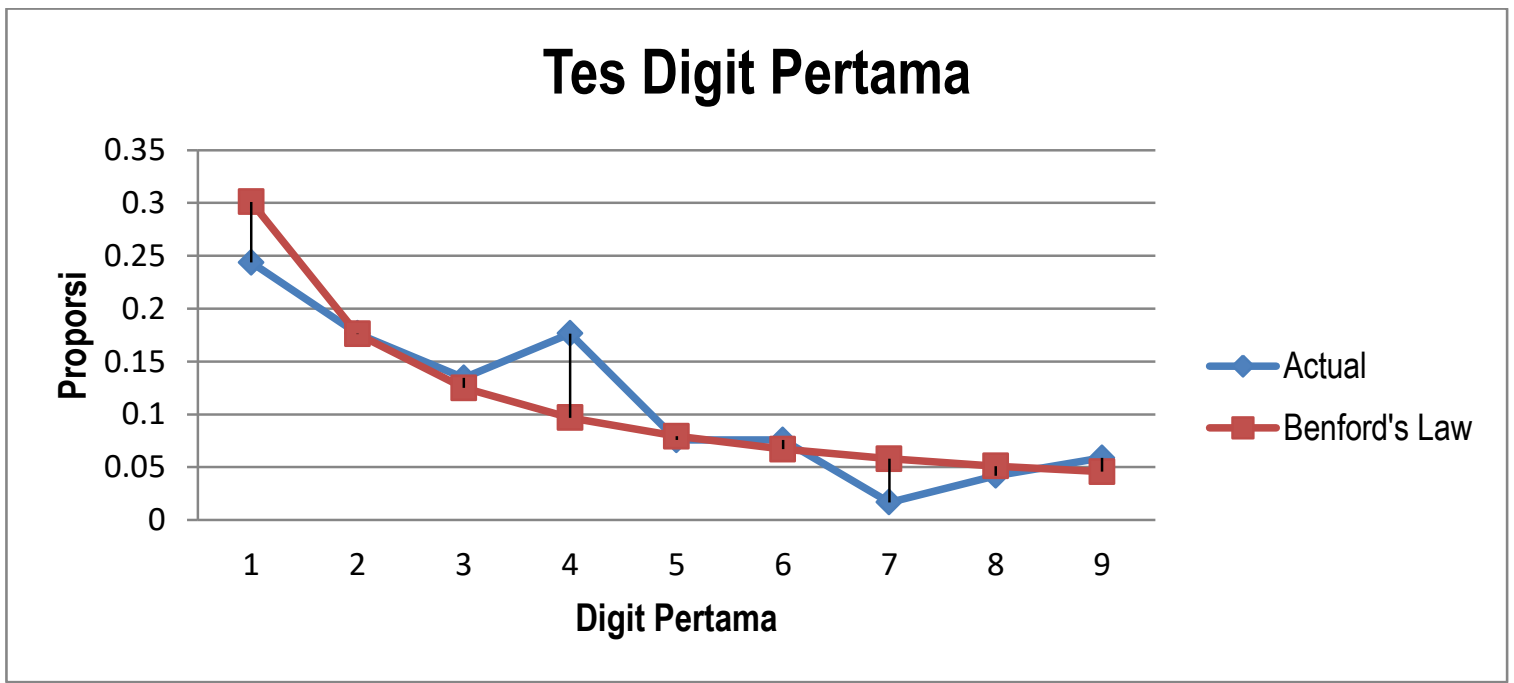

Jika pembuktian atas penyimpangan ini dijadikan sebagai pedoman dalam mencari petunjuk audit maka dapat dilihat bahwa dalam laporan keuangan PT Garuda Indonesia (Persero) Tbk. Tahun 2017 terdapat beberapa akun yang patut dicurigai. Akun-akun tersebut mengandung nilai nominal yang diawali dengan angka 4 (empat), berikut ini merupakan tampilan tabel kesesuaian antara akun-akun yang ditemukan menyimpang di tahun 2017 dan juga masuk dalam daftar untuk disajikan ulang kembali di tahun 2018:

Tabel 9. Daftar Akun-akun yang mengalami Re-stated di Tahun 2018 dan sekaligus Menyimpang dari Distribusi Normal Hukum Benford pada Laporan Keuangan Tahun 2017

\begin{tabular}{llcl}
\hline \multicolumn{1}{c}{ Nama Akun } & $\begin{array}{c}\text { Re-stated } \\
\text { OJK } \\
\mathbf{2 0 1 8}\end{array}$ & $\begin{array}{c}\text { Melawan } \\
\text { Hukum } \\
\text { Benford } \\
\mathbf{- 2 0 1 7}\end{array}$ & Kesimpulan \\
\hline 1. Pendapatan (Beban) Lain-lain & $\sqrt{ }$ & $\sqrt{ }$ & \\
2. Penerimaan Pengembalian Dana & $\mathbf{X}$ & $\sqrt{ }$ & $\begin{array}{c}\text { Setidaknya terdapat } 4 \text { buah } \\
\text { akun yang mengalami } \\
\text { keterkaitan antara tahun 2017 } \\
\text { dari Pemeliharaan Pesawat }\end{array}$ \\
3. Pembayaran Uang Jaminan & $\mathbf{X}$ & $\sqrt{ }$ & dan tahun 2018, di antaranya: \\
4. Hasil Pelepasan Aset Tetap & $\mathbf{X}$ & $\sqrt{ }$ & i. Pendapatan (Beban) \\
5. Penerimaan Dividen & $\mathbf{X}$ & $\sqrt{ }$ & Lain-lain \\
6. Keuntungan Selisih Kurs & $\sqrt{ }$ & $\mathbf{X}$ & ii. Piutang Usaha Lain- \\
7. Liabilitas Tidak Lancar Lainnya & $\mathbf{X}$ & $\sqrt{ }$ & lain \\
8. Piutang Usaha Lain-lain & $\sqrt{ }$ & $\sqrt{ }$ &
\end{tabular}




\begin{tabular}{|c|c|c|c|}
\hline 9. Aset Pajak Tangguhan & $\sqrt{ }$ & $\mathbf{X}$ & Utang Pajak \\
\hline 10. Utang Pajak & $\sqrt{ }$ & $\sqrt{ }$ & Saldo Laba/Rugi yang \\
\hline 11. Liabilitas Pinjaman Jangka & $\sqrt{ }$ & $\mathbf{X}$ & belum dicadangkan \\
\hline Pendek & & & Keempat akun tersebut \\
\hline $\begin{array}{l}\text { 12. Liabilitas Pinjaman Jangka } \\
\text { Panjang }\end{array}$ & $\sqrt{ }$ & $\mathbf{X}$ & $\begin{array}{l}\text { memiliki pengaruh satu sama } \\
\text { lain, yang berarti jika salah }\end{array}$ \\
\hline 13. Utang Lain-lain & $\mathbf{X}$ & $\sqrt{ }$ & satu dari akun-akun tersebut \\
\hline $\begin{array}{l}\text { 14. Liabilitas Pinjaman Jangka } \\
\text { Panjang Obligasi }\end{array}$ & $\mathbf{X}$ & $\sqrt{ }$ & $\begin{array}{l}\text { mengalami overstated maka } \\
\text { akan memberikan pengaruh }\end{array}$ \\
\hline 15. Manfaat (Beban) Pajak & $\sqrt{ }$ & $\mathbf{X}$ & yang sama terhadap ketiga \\
\hline $\begin{array}{l}\text { 16. Saldo Laba/Rugi yang belum } \\
\text { dicadangkan }\end{array}$ & $\sqrt{ }$ & $\sqrt{ }$ & $\begin{array}{l}\text { akun yang lain, dan begitu pun } \\
\text { sebaliknya (jika understated). }\end{array}$ \\
\hline 17. Penghasilan Komprehensif Lain & $\mathbf{X}$ & $\sqrt{ }$ & Tentunya hal ini akan \\
\hline 18. Kepentingan Non-pengendali & $\mathbf{X}$ & $\sqrt{ }$ & mengakibatkan adanya \\
\hline 19. Penerimaan Kas Pelanggan & $\mathbf{X}$ & $\sqrt{ }$ & kerancuan informasi bagi para \\
\hline $\begin{array}{l}\text { 20. Pengaruh Perubahan Kurs } \\
\text { Valutas Asing }\end{array}$ & $\mathbf{X}$ & $\sqrt{ }$ & stakeholder. \\
\hline
\end{tabular}

Sumber : Hasil olahan Penulis

Seperti yang kita ketahui bersama bahwa untuk mendukung nilai laba yang telah dimanipulasi, maka diperlukan juga beberapa manipulasi tambahan, setidaknya beberapa akun di pelaporan neraca dan laporan laba rugi. Seperti halnya dalam kasus Garuda, yang mencoba untuk mengakui pendapatan lebih awal di tahun 2018 agar dapat menutupi kondisi keuangan perusahaan yang telah merugi selama beberapa tahun terakhir. Pengakuan pendapatan yang lebih awal ini, selanjutnya berusaha diseimbangkan dengan menambah nilai piutang lain-lain dan kemudian berdampak pada penambahan nilai utang pajak. Pada prinsipnya adalah untuk menutupi sebuah kebohongan atau penipuan (fraud) maka diperlukan kebohongan-kebohongan lain (fraud tambahan) agar semuanya dapat terlihat menjadi wajar.

\section{Kesimpulan}

Hukum Benford adalah alat uji yang sangat berguna dalam mendeteksi adanya manipulasi data keuangan. Mengapa demikian, karena hukum ini telah terbukti memiliki beberapa kelebihan yang membuatnya berpotensi menjadi alat bantu audit dalam menguji validitas data keuangan, di antaranya:

1. Laporan Keuangan PT Garuda Indonesia (Persero) Tbk. Tahun 2018 yang telah mengalami restatement atau penyajian ulang kembali sesuai dengan Surat Otoritas Jasa Keuangan No. S-21/PM.1/2019 telah teruji mengikuti distribusi data Hukum Benford. Oleh karena itu dapat disimpulkan pola distribusi angka dalam hukum ini juga sejalan dengan skema penyusunan laporan keuangan yang baik dan benar

2. Terdapat salah satu penyimpangan yang signifikan atas proporsi data laporan keuangan PT Garuda Indonesia (Persero) Tbk. Tahun 2017 yakni pada hasil Tes Digit Pertama dan angka ke-empat. Jika disimak lebih lanjut, penyimpangan data dari beberapa akun ini (dengan nilai nominal yang diawali angka empat) yang kemudian pada tahun 2018 diminta untuk disajikan ulang kembali atau mengalami Re-stated, sesuai dengan permintaan badan Otoritas Jasa Keuangan (Surat Otoritas Jasa Keuangan No. S21/PM.1/2019).

\section{Daftar Pustaka}

Association of Certified Fraud Examiners, USA (2018). "Using Benford's Law to Detect Fraud". Final Extract. Diakses pada 12 Mei 2020, dari https://www.acfe.com/ 
Benford, F (1938). "The law of anomalous numbers", Proceedings of the American Philosophical Society, vol.78, no. 4, hal. 551-572.

Drake, P. D., dan M. J. Nigrini. 2000. Computer assisted analytical procedures using Benford's Law. Journal of Accounting Education 18 (2): 127-146.

Durtschi, C., W. Hillison, and C. Pacini. 2004. The Effective Use of Benford's Law in Detecting Fraud in Accounting Data. Journal of Forensic Accounting 5: 17-34.

Carslaw, C. (1988). "Anomalies in income numbers: evidence of goal oriented behavior". The Accounting Review, vol. 63, no. 2, hal. 321-327.

Jerry J. Weygandt, Paul D. Kimmel, Donald E. Kieso. (2018). "Accounting Principles", $13^{\text {th }}$ Edition, ISBN: 978-1-119-41101-7 January 2018

Kellerman. (2014). "Evaluating the effectiveness of Benford's law as an investigative tool for forensic accountants". Dissertation May 2014. North-West University

Kristian Agung Prasetyo dan Suhut Tumpal Sinaga. (2014). "Aplikasi Benford Law untuk Mengidentifikasi Ketidakpatuhan SPT Wajib Pajak". Kajian Akademis BPPK Tahun Anggaran 2014. Badan Pendidikan dan Pelatihan Keuangan. Kementerian Keuangan Republik Indonesia.

Mihkel Tammaru \& Lehte Alver. (2016). "Application of Benford's Law for Fraud Detection in Financial Statements: Theoretical Review". Conference Paper January 2016. DOI: 10.2991/icaat-16.2016.46

Newcomb, S. (1881). "Note on the frequency of use of the different digits in natural numbers". American Journal of Mathematics, Vol. 4 no. 1, hal. 39-40.

Nigrini, M. J. (1996). "A taxpayer compliance application of Benford's law". Journal of the
American Taxation Association, vol. 18, no. 1, hal. 72-91.

Nigirini M. J. (2000). "Digital Analysis Using Benford's Law tests \& statistics for auditors". Global Audit Publications hal. 278

Nigrini, M. J. 2011. Forensic Analytics Methods and Techniques for Forensic Accounting Investigations. Hoboken, NJ: John Wiley \& Sons.

Nigrini, M. J. 2012. Benford's Law Applications for Forensic Accounting, Auditing, and Fraud Detection. Hoboken, NJ: John Wiley \& Sons.

PSAK 72 (Pernyataan Standar Akuntansi Keuangan) Dewan Standar Akuntansi Keuangan Indonesia, Dewan Standar Akuntansi Keuangan Indonesia, Standar Akuntansi Keuangan - Ikatan Akuntan Indonesia, 2018, Ikatan Akuntan Indonesia, Jakarta, Indonesia.

Quick dan Wolz. 2003. Benford's Law in deutschen Rechnungslegungsdaten. Betriebswirtschaftliche Forschung und Praxis 2: 208-224

Thomas, J. (1989). "Unusual patterns in reported earnings". The Accounting Review, vol. 64, no. 4, 773-787.

Watrin, C., R. Struffert, dan R. Ullmann. 2008. Benford's Law: an instrument for selecting tax audit targets? Review of Managerial Science 2: 219-237. www.cnnindonesia.com. (2019, 24 April). Membedah Keanehan Laporan Keuangan Garuda Indonesia 2018. Diakses pada 10 Juni 2020, dari https://www.cnnindonesia.com/eko nomi

www.cnnindonesia.com. (2019, 30 April). Kronologi Kisruh Laporan Keuangan Garuda Indonesia. Diakses pada 12 Juni 2020, dari https://www.cnnindonesia.com/eko nomi 
www.garuda-indonesia.com.

(2018).

Laporan Keuangan Konsolidasian untuk Tahun yang Berakhir 31 Desember 2017 dan Laporan Audit Independen. Diakses pada 5 Juni 2020, dari www.garudaindonesia.com/content/dam/garuda/ files/pdf/

www.garuda-indonesia.com.

Laporan Keuangan Konsolidasian untuk Tahun yang Berakhir 31 Desember 2018 dan Laporan Audit Independen. Diakses pada 5 Juni 2020, dari www.garudaindonesia.com/content/dam/garuda/ files/pdf/

www.garuda-indonesia.com. (2019, 26 Juli). Paparan Publik Insidentil Penyajian Kembali Laporan Keuangan Periode FY2018 dan 1Q2019. Diakses pada 13 Juli 2020, dari www.garudaindonesia.com/content/dam/garuda/ files/pdf/ 